\title{
The Early Cambrian Mianyang-Changning Intracratonic Sag and Its Control on Petroleum Accumulation in the Sichuan Basin, China
}

\author{
Shugen Liu, ${ }^{1}$ Bin Deng, ${ }^{1}$ Luba Jansa, ${ }^{2}$ Yong Zhong, ${ }^{3}$ Wei Sun, ${ }^{1}$ Jinmin Song, \\ Guozhi Wang, ${ }^{1}$ Juan Wu, ${ }^{1}$ Zhiwu Li, ${ }^{1}$ and Yanhong Tian ${ }^{1}$ \\ ${ }^{1}$ State Key Laboratory of Oil and Gas Reservoir Geology and Exploitation, Chengdu University of Technology, Chengdu 610059, China \\ ${ }^{2}$ Geological Survey of Canada-Atlantic, Dartmouth, NS, Canada \\ ${ }^{3}$ Sichuan Geophysical Company of CNPC Chuanqing Drilling Engineering Company Limited, Chengdu 610213, China \\ Correspondence should be addressed to Shugen Liu; 1sg@cdut.edu.cn and Bin Deng; dengbin3000@163.com
}

Received 2 March 2017; Accepted 1 June 2017; Published 16 August 2017

Academic Editor: Xiaorong Luo

Copyright (c) 2017 Shugen Liu et al. This is an open access article distributed under the Creative Commons Attribution License, which permits unrestricted use, distribution, and reproduction in any medium, provided the original work is properly cited.

\begin{abstract}
The older and deeper hydrocarbon accumulations receive increasing attention across the world, providing more technical and commercial challenges to hydrocarbon exploration. We present a study of an asymmetrical, N-S striking intracratonic sag which developed across the Sichuan basin, south China, from Late Ediacaran to Early Cambrian times. The Mianyang-Changning intracratonic sag is $\sim 50 \mathrm{~km}$ wide, with its steepest part in the basin center. In particular the eastern margin shows its greatest steepness. Five episodes in the evolutions of the sag can be recognized. It begins in the Late Ediacaran with an uplift and erosion correlated to Tongwan movement. Initial extension occurred during the Early Cambrian Maidiping period, when more strata of the Maidiping Formation were deposited across the sag. Subsequently, maximum extension occurred during the Early Cambrian Qiongzhusi period that resulted in 450-1700 m thick Maidiping-Canglangpu Formations being deposited in the sag. Then, the sag disappeared at the Longwangmiao period, as it was infilled by the sediments. The intracratonic sag has significant influence on the development of high-quality reservoirs in the Dengying and Longwangmiao Formations and source-rock of the Niutitang Formation. It thus indicates that a high probability for oil/gas accumulation exists along the intracratonic sag, across the central Sichuan basin.
\end{abstract}

\section{Introduction}

Continental rift basins are widespread extensional structures on the Earth's surface and are known from the Archean up to the present. They account for $\sim 30 \%$ of global hydrocarbon discoveries [1]. In particular, the Neoproterozoic assembly and break-up of two supercontinents, that is, Rodinia and Greater Gondwana, were marked by the development of a long series of rift valleys, half-graben, pull-apart basins, and intramontane molasse basins, along the Peri-Gondwanan Margin, from Australia through Pakistan, Oman and North Africa, and South China block (Figure 1(a)) [2,3]. A series of studies was undertaken to unravel the generation and accumulation of hydrocarbons in this unique geological time [4-7]. The area which was particularly intensively studied is the South Oman Salt Basin $[8,9]$. In most of these areas, the Neoproterozoic-Early Cambrian organic-rich strata are widespread, forming the Neoproterozoic-Early Cambrian ("Infra-Cambrian" [10]) hydrocarbon plays. The occurrence of prolific source-rocks was controlled by strong postglacial sea-level rise, following the major Neoproterozoic glaciations [2]. Furthermore, deposits of evaporites and black shale are widespread in rift-related basins, providing effective seal and source-rock across from Oman, Pakistan, and India to South China $[3,11]$. This generated an interest in exploring for the Infra-Cambrian plays along the Peri-Gondwanan Margin. Despite the existence of proven Infra-Cambrian hydrocarbon plays in many parts of the world, the petroleum prospective is associated with much higher exploration risks than in conventional Phanerozoic petroleum systems, as the strata 

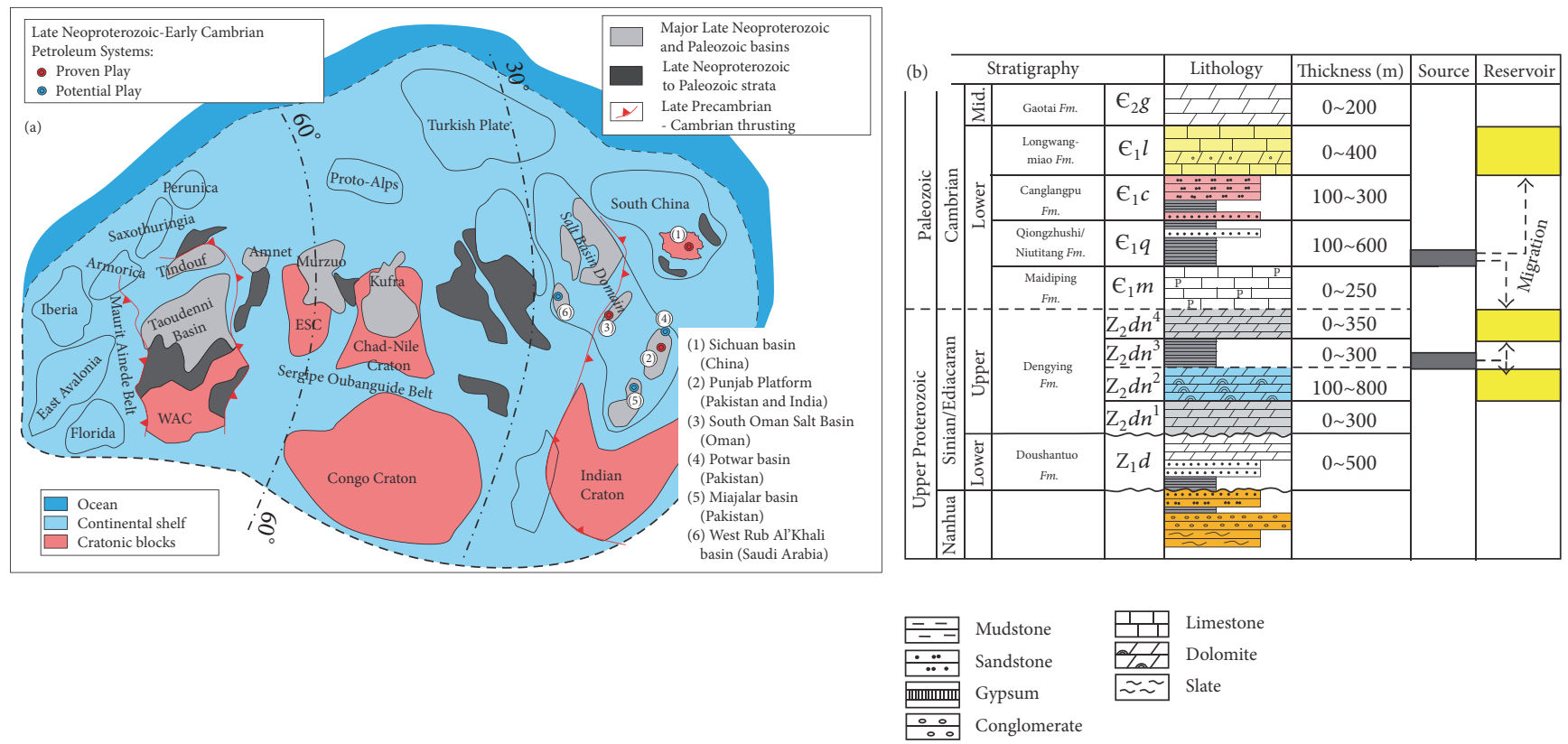

$102^{\circ} \mathrm{E}$

$104^{\circ} \mathrm{E}$

$106^{\circ} \mathrm{E}$

$108^{\circ} \mathrm{E}$

$110^{\circ} \mathrm{E}$

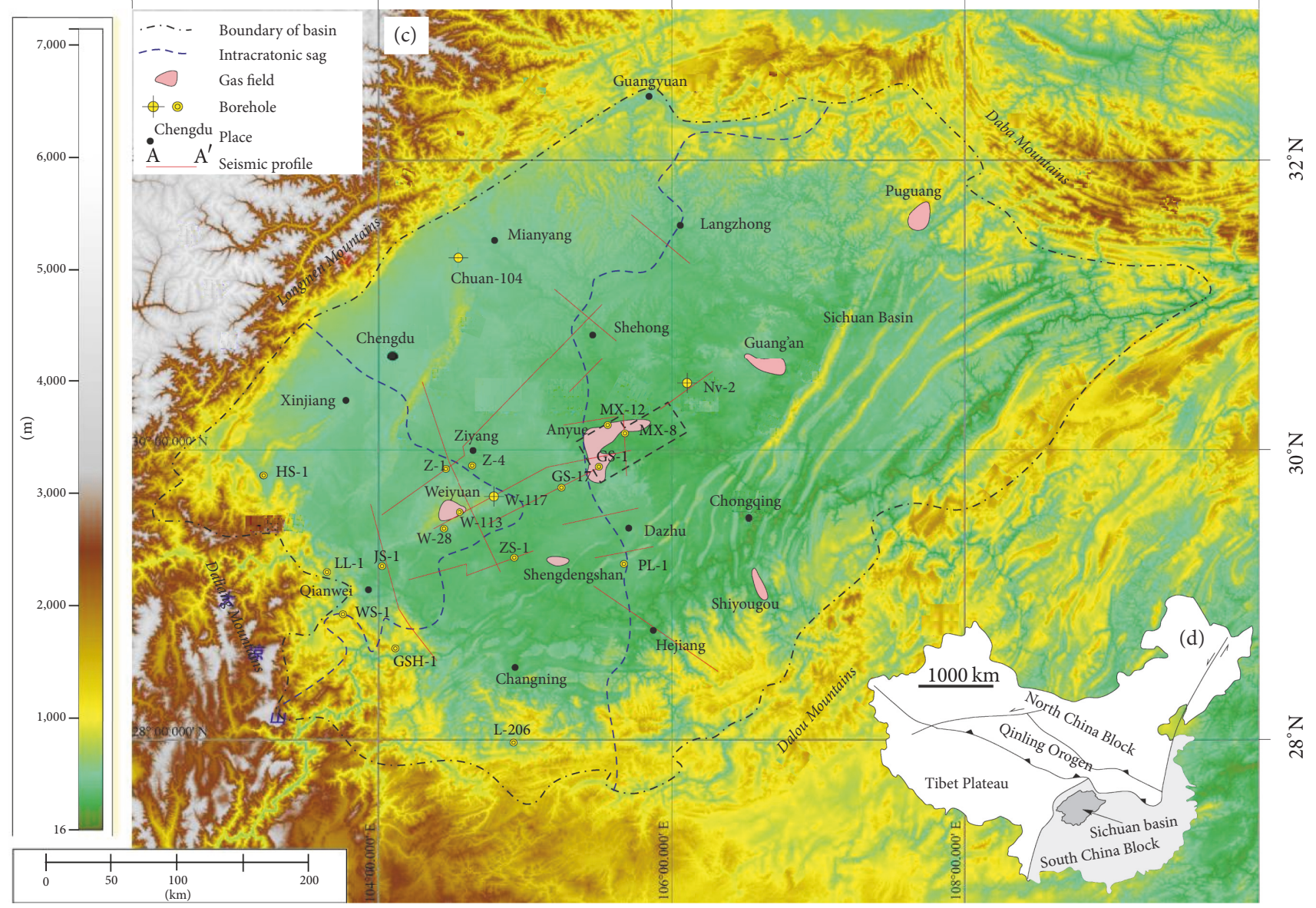

Figure 1: (a) Generalized Late Neoproterozoic-Early Cambrian palaeogeography of the "Peri-Gondwanan Margin" and its petroleum system (modified from Craig et al. [2]). (b) Late Neoproterozoic-Middle Cambrian Stratigraphic column for the South China block. (c) The Digital Elevation Map (DEM) showing the topography and intracratonic sag in the Sichuan basin, the red lines indicating 2D seismic profiles to unravel the sag structure, and the black dotted line showing 3D seismic data of the Gaoshiti-Moxi area. (d) Insert: map of the basic tectonic framework of China. 
are usually much more deeply buried and relatively poorly known.

The Sichuan basin located in the South China continental block has generated interest for brine/natural gas exploration since the $\sim 1100 \mathrm{AD}[12]$ and is one of the largest sedimentary basins rich in petroleum resources in China (Figure 1). It is noteworthy to mention that workers in the old salt industry have used bamboo casing and piping to drill for gas near Zigong, in the southern Sichuan basin. This idea inspired the first significant gas pools discovery in the Shiyougou and Shengdengshan structures in the 1930s, followed later by a series of oil/gas discoveries in the Sichuan basin (Figure 1), for example, Well Nv-2 in 1958 and the Ediacaran Weiyuan gas fields in 1964 (with a proven in-place gas volume of $408.6 \times 10^{8} \mathrm{~m}^{3}$ (1.5 tcf), etc.) [13-15]. In particular, recent major discoveries are genetically related to NeoproterozoicPaleozoic extensional tectonics across the basin, for example, Puguang gas field with a proven in-place gas volume of $3500 \times$ $10^{8} \mathrm{~m}^{3}$ (12.4 tcf) [16] and the Anyue gas field with a volume of $4403.8 \times 10^{8} \mathrm{~m}^{3}$ (15.6 tcf) [17]. The later Ediacaran-Cambrian carbonate gas field is also the biggest gas field presently in China. Based on seismic data, structural features, hydrocarbon condition, and so on, we reconstruct the Early Cambrian extensional structure, that is, the Mianyang-Changning intracratonic sag located in the basin center, and discuss its influence on petroleum accumulation. It may stimulate further exploration in these hydrocarbon rich provinces.

\section{Geological Setting}

The Sichuan basin is located at the western margin of the South China block, which is comprised of the Yangtze platform in the northwest and the Cathaysian Block in the southeast (Figure 1). To the north, it is separated from the North China block by the Late Paleozoic to Middle Mesozoic Qinling Orogen [19], and to the west from the MesozoicCenozoic Eastern Tibetan Plateau by the Longmen-Daliang thrust fold belt $[20,21]$. Within the South China block, the Sichuan basin is separated from a $1300-\mathrm{km}$ wide Mesozoic intracontinental orogenic belt by the Qiyueshan-Daloushan structure $[22,23]$. Thus, the Sichuan basin is a superimposed basin influenced by its peripheral orogens and dominated by four stages of basin evolution: (a) a rift at the cratonic margin in the Neoproterozoic, (b) a marine carbonate platform from the Early Cambrian to Middle Triassic, (c) a foreland basin from Late Triassic to Late Cretaceous, and (d) subsequent exhumation and structural modification. The sedimentary cover is comprised mainly of Paleozoic and Middle Mesozoic strata of shallow-marine deposits, and post-Late Triassic terrestrial strata, of a total thickness $\sim 8 \mathrm{~km}$ to $12 \mathrm{~km}$.

The South China block is generally considered being a part of the Precambrian Rodinia supercontinent [24-26]. Along its western and northern margins, the Proterozoic basement of the craton, that is, the Kongling complex or Banxi group, is characterized by the presence of migmatitic granites and gneiss, a metamorphosed greywacke-slate succession, unconformably overlain by the Sinian/Ediacaran sedimentary rocks. The Sinian/Ediacaran Doushantuo and Dengying formations deposited during a major marine transgression are predominantly comprised of shallow water dolomitic carbonates. Due to the Tongwan tectonic movement, Sinian (Ediacaran) dolomites were exposed to freshwater karstification, resulting in widespread development of caverns and dissolution porosity in the upper of Dengying Formation and at unconformities (Figure 1(b)) [27, 28]. That becomes a favorable niche for petroleum accumulation in the Proterozoic Dengying Formation, as demonstrated by the Weiyuan gas field with proven gas reserves of $408.61 \times 10^{8} \mathrm{~m}^{3}$ (1.5 tcf) [29]. Furthermore, the major extensional movements in the Sichuan basin were the Xinkai taphrogenesis or "extensional movement," which is coeval with assembly and breakup of the Rodinia supercontinent [30-33]. It resulted in the formation of deep extensional faults representing favorable conduits for thermal fluids migration from the deep basin. The evidence is widespread dissolution, precipitation of silica, occurrence of zebra structures, and saddle dolomite in the Late Proterozoic strata, improving the reservoir quality of the Dengying Formation, which widely host the lead-zinc deposits of MVT type and barite-fluorite and hydrothermal chert along the western margin of the South China block [3436]. The Early Cambrian strata paraconformably overlie the Sinian (Ediacaran) rocks. In particular, the Qiongzhushi Formation (or Niutitang Formation) is one of the most important source-rocks (dominated by Type I-kerogen) in the basin, which generated hydrocarbons found in the Upper Sinian and Early Cambrian formations reservoirs [37-39]. Recently, another giant gas field has been discovered in coarsely crystalline dolomite facies, in the Cambrian Longwangmiao Formation, with proven gas reserves of $4403.8 \times 10^{8} \mathrm{~m}^{3}$ (16.2 tcf).

During Mesozoic to Cenozoic times, the area was affected by several phases of tectonic movements, including the Caledonian movement and Indosinian and Yanshannian movements $[40,41]$. This resulted in most of the upper Silurian, Devonian, and Carboniferous strata being absent across the South China block, in the development of several regional unconformities and an E-W trending Leshan-Longnvshi paleouplift in the Sichuan basin center. These structures significantly influenced the formation of the carbonate reservoirs and hydrocarbon accumulations across the Sichuan basin and its periphery $[7,29,38]$. Furthermore, those multiphase tectonic movements gave rise to a complicated tectonic evolution and sedimentary history of the basin [42, 43].

\section{The Early Cambrian Mianyang-Changning Intracratonic Sag}

3.1. Precambrian Extensional Faults across the Sichuan Basin. Stratigraphic horizons were mapped in the Gaoshiti-Moxi area, located in the center of the Sichuan basin, using the three-dimensional seismic data and well control (Figure 1(c)). We observed that extensional faults are extremely common in most of the Precambrian strata (Figure 2) (see Supplementary Material, available online at https://doi.org/10.1155/2017/ 6740892). There are at least two extensional faults present with an opposite dip, indicating a rift. The continuity of reflectors indicates presence of syn-rift deposits. Furthermore, an offset of extensional faults is well imaged in the 


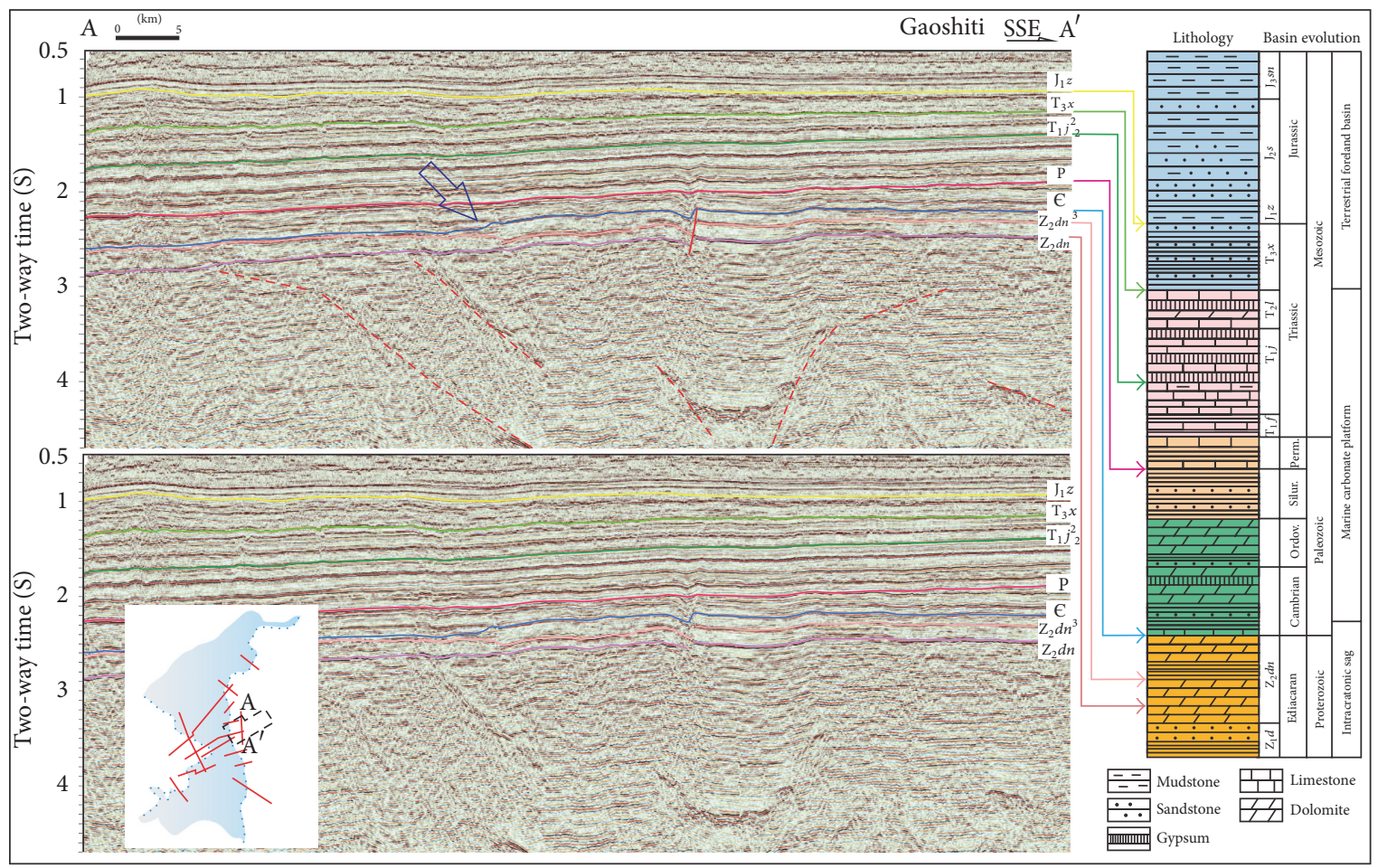

Figure 2: 3D seismic profile indicating Precambrian extensional structure in the center of the Sichuan basin (please find the original data in Supplementary Material). The red dotted line and blue arrow show the pre-Sinian extensional faults and eastern boundary of extensional structure; the inset box shows the location ( $\mathrm{J}_{1} z$ : base of Lower Jurassic Zhiliujing Formation, $\mathrm{T}_{3} x$ : base of Upper Triassic Xujiahe Formation, $\mathrm{T}_{1} j^{2}$ : base of the second member of Lower Triassic Jialingjiang Formation, P: base of Permian, $\epsilon$ : base of Cambrian, $Z_{2} d n^{3}:$ base of the third member of Sinian Dengying Formation).

seismic data. This structural model was used as the basis for our 2D and 3D interpretation across the Sichuan basin. The density of seismic profiles is $5-30 \mathrm{~km}$ across most of the basin. The data shows that there are many extensional faults and related structures in the Precambrian strata, across the Sichuan basin. Most of these structures have NE-strike; some of extensional structures further show the influence of the deformation of the overlain strata. In particular, some of the strata overlying the extensional structures (i.e., Upper Sinian Dengying and Lower Cambrian sequences) are characterized by distinctly increased thickness (Figure 2).

\subsection{Boundary of the Mianyang-Changning Intracratonic Sag.} As borehole data for pre-Sinian strata are lacking, therefore there is much of uncertainty about the rifts. However, based on regional geology studies [30-33], we argue that such extensional tectonics extended across the Ediacaran (Sinian) to Early Cambrian periods. Occurrence of extensional tectonics is supported by the borehole data of the Sinian strata and related seismic data, which indicate presence of Early Cambrian extensional structures across the Sichuan basin. The borehole data indicates that there is distinct increased thickness of the Early Cambrian Qiongzhusi Fm in the GS-17 and Z-4 wells, located at the hanging walls of the extensional faults mentioned above, in comparison with W-28 and GS1 wells located at the footwalls. In particular, there is an additional strata, the Maidiping Fm, in the center of the extensional structure, compared to other places (Table 1, Figure 3). Thus, we argue that there is an extensional structure across the center of Sichuan basin, named the MianyangChangning intracratonic sag. We use the term "intracratonic sag" according to P. A. Allen and J. R. Allen [44], as it is difficult to identify how large the offset of extensional faults was during the Early Cambrian periods.

Most of the seismic profiles across the Mianyang-Changning intracratonic sag show significant changes in the thickness of Early Cambrian strata; those stara westwards and eastwards onlap onto the Sinian strata, with decreasing thickness from the center of the sag to its sides. It should be noted that the underlain Late Sinian strata show decreasing thickness towards the boundary of the sag. The continuity of reflection horizons suggests asymmetric geometry of the MianyangChangning intracratonic sag, with a steep boundary at the eastern margin, where the discontinuous reflections indicate that it probably accommodated some extensional faults to result in a dustpan-like geometry.

From north to south, the seismic data shows an increasing steepness along the eastern margin of the sag, for example, from the Langzhong to the Shehong sections (Figure $4 \mathrm{D}$ $\mathrm{D}^{\prime}$ section), where the orientation of eastern margin changes from NE-striking to NS-striking in the Shehong area. At the center of the Sichuan basin the increased thickness of Early Cambrian strata is consistent with overlain extensional faults in pre-Cambrian strata in the Gaoshiti-Moxi area 


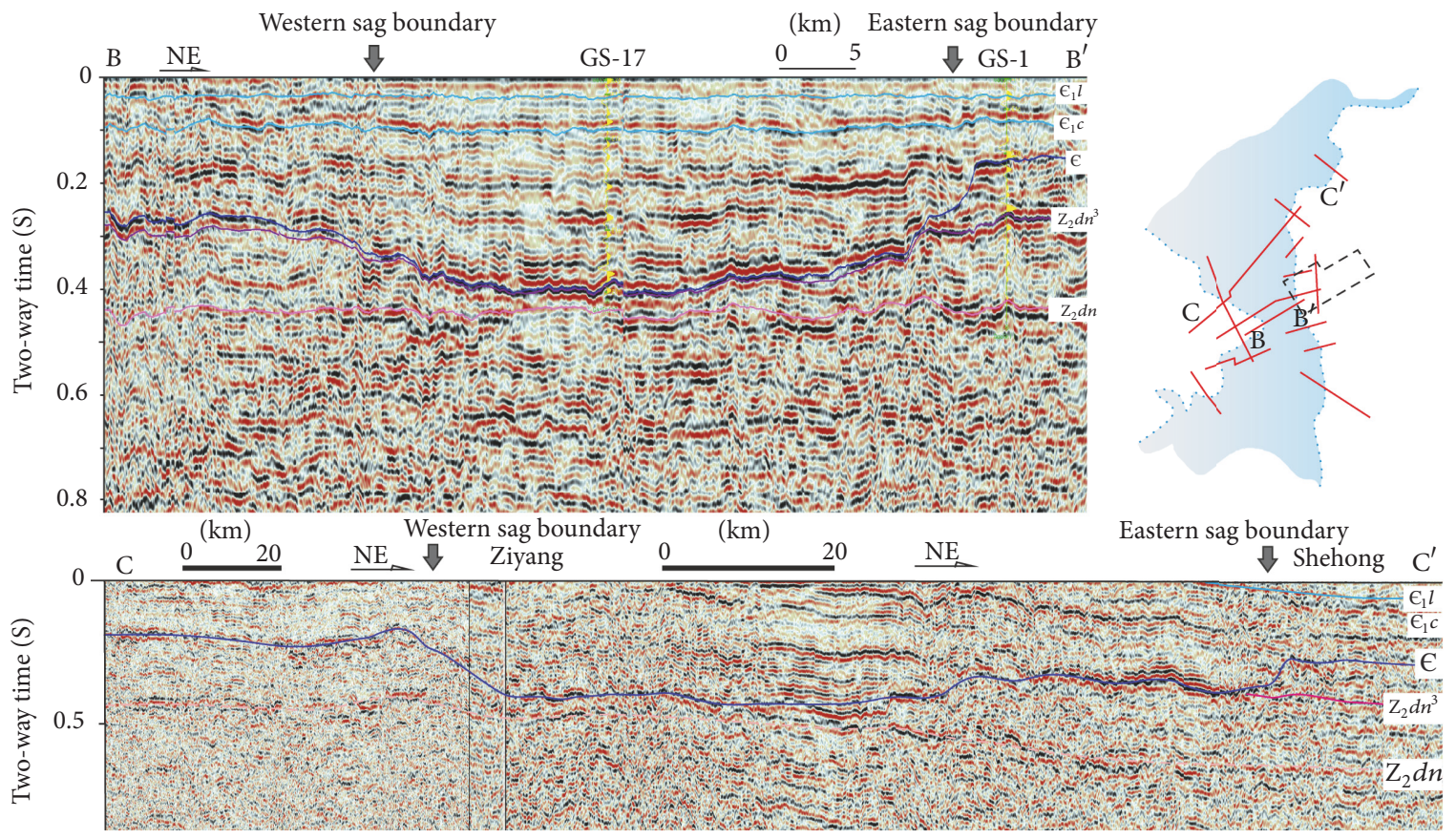

Figure 3: The key seismic profiles indicating presence of Early Cambrian extensional intracratonic sag across the Sichuan basin. (B-B': NEstriking Weiyuan-Gaoshiti cross-section across the intracratonic sag. The yellow lines show log-data for well picks of the horizon; based on GS-1 and GS-17 wells. Grey arrows show western and eastern sag boundaries. $\epsilon_{1} l$ and $\epsilon_{1} c$ are bases of Lower Cambrian Longwangmiao and Canglangpu Fm. C-C': NE-striking Ziyang-Shehong section. All the seismic profiles are rotated back with the Middle Cambrian Gaotai Fm. The inset map shows locations of cross-sections).

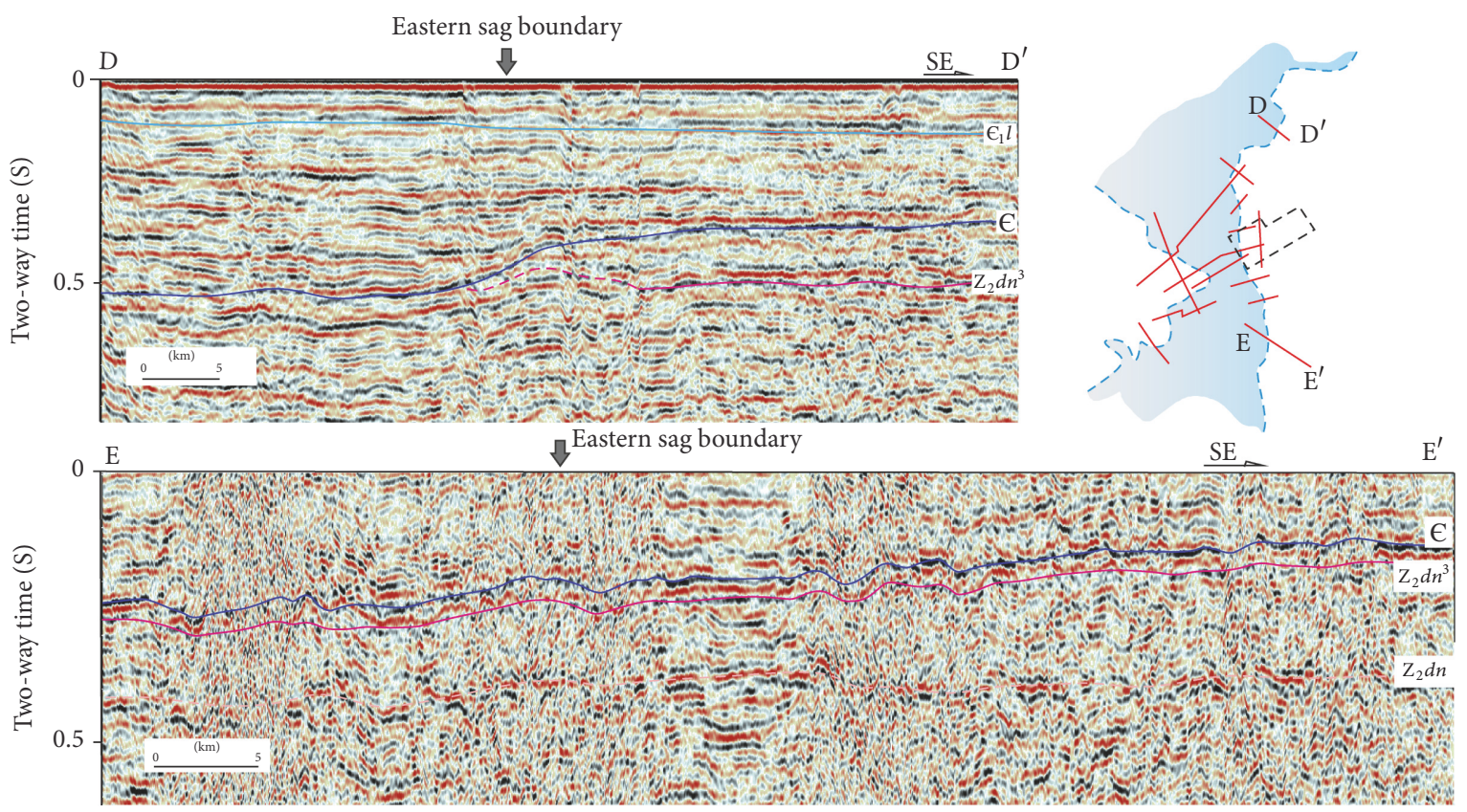

Figure 4: 2D seismic profile across eastern margin of the Mianyang-Changning intracratonic sag. D-D': SE-striking Langzhong section in northern segment of the sag; E- $E^{\prime}$ : SE-striking Hejiang section in southern segment. It should be noted that there is a distinct decrease in the steepness of the eastern boundary from the north to the south. 


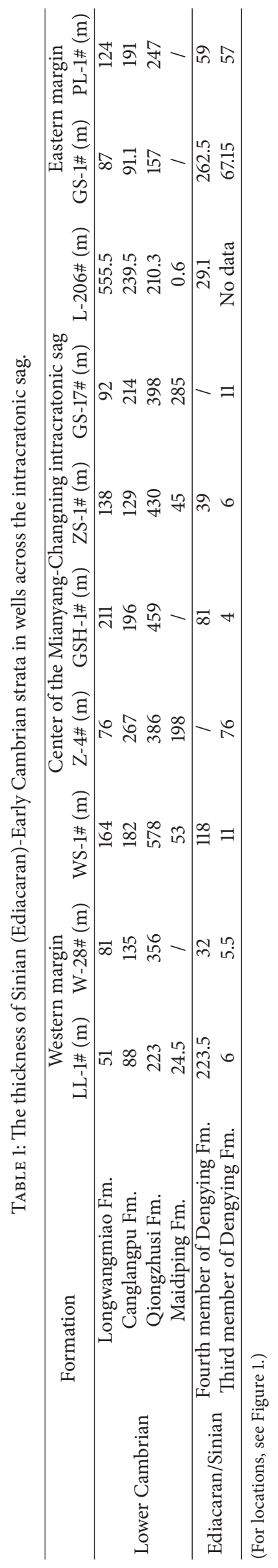




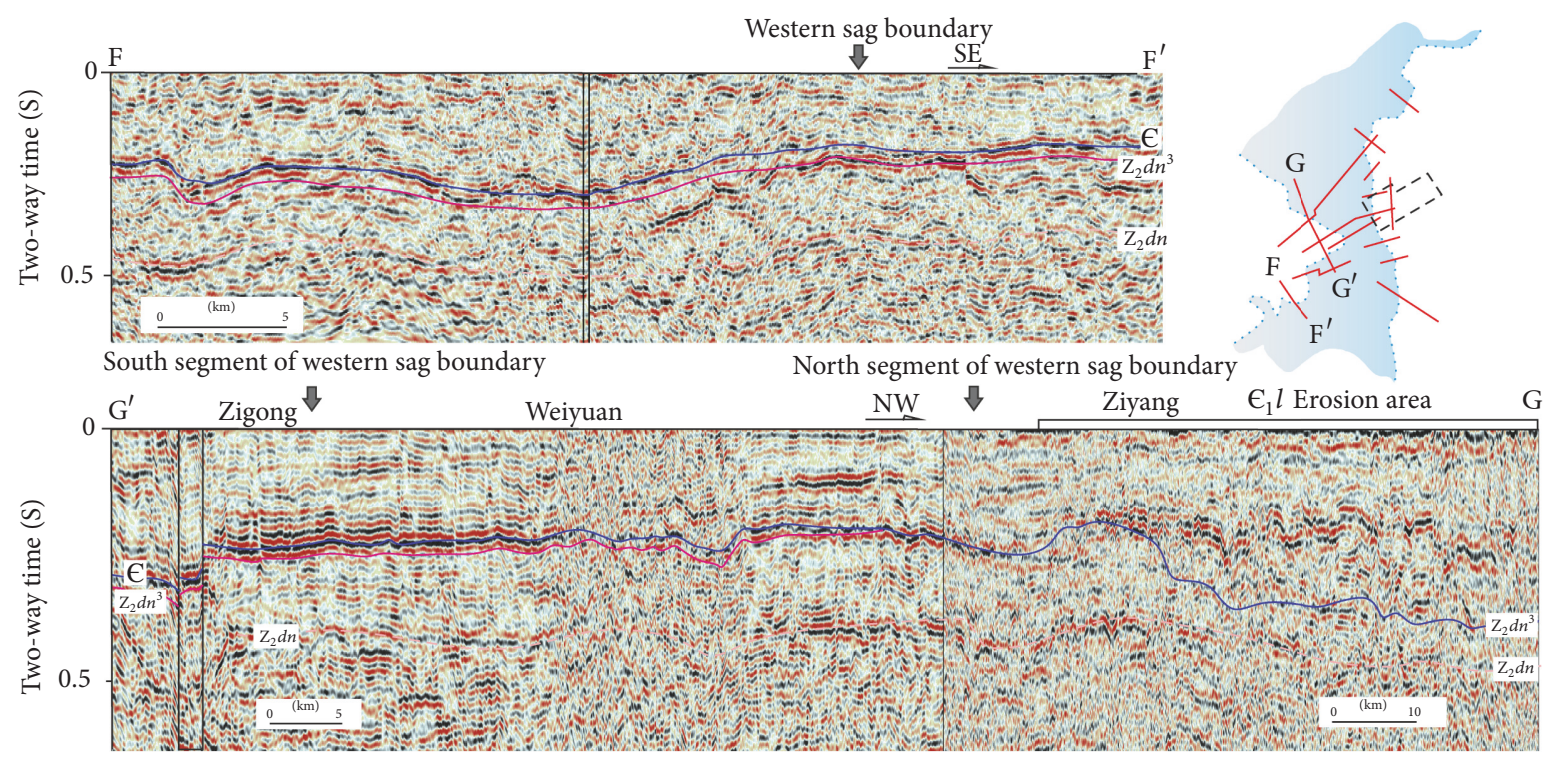

FIGURE 5: 2D seismic profile across western margin of the Mianyang-Changning intracratonic sag. F-F': SE-striking Qianwei section in southern segment of the sag; G-G': NW-striking Zigong-Ziyang section, showing a distinct decrease in steepness of the western sag boundary from the north to the south.

(Figure 2). The discontinuous reflections at the base of the Early Cambrian strata suggest a steeper margin of the Mianyang-Changning intracratonic sag than at its northern segment (Figure 3). Further to the south, the steepness of eastern margin substantially decreases, as can be observed at, for example, the Dazhu and Hejiang areas (Figure 4 E-E ${ }^{\prime}$ section).

The western margin of the sag as indicated by seismic profiles is characterized by less steep beds and more complicated strata orientation than that of the eastern margin. The western margin can be subdivided into two segments, one is NW-striking and the other NE-striking, separated by the Weiyuan-Zigong area. In the south, both the south segment of western margin and south segment of the eastern margin are characterized by low steepness (Figure 5 F- $\mathrm{F}^{\prime}$ section and Figure $4 \mathrm{E}-\mathrm{E}^{\prime}$ section). Although the western margin of the Mianyang-Changning intracratonic sag shows generally less steepness than the eastern margin (Figure 3), the northern segment of western margin of the sag is much steeper than its southern segment (Figure 5 G-G' ${ }^{\prime}$ section). It should be noted that the underlying Dengying Formation is thinner along the western margin than at the eastern margin of the sag. That is a result of the uplift and erosion which occurred during the end of the Ediacaran epoch [30-32].

3.3. Geometry of the Mianyang-Changning Intracratonic Sag. We have used seismic lineups at the base of the Early Cambrian Maidiping and Canglangpu formations to unravel spatial thicknesses of the deposits during Early Cambrian times. It demonstrates syn-extension sedimentation during that time and shows geometry of the Mianyang-Changning intracratonic sag across the Sichuan basin (Figure 6). The isopach map (Figure 6(a)) shows thickest MaidipingCanglangpu Formations to be located in the center of the
Sichuan basin, where the thickness is about $450-1700 \mathrm{~m}$ higher than $0-600 \mathrm{~m}$ at any other place. It suggests that a geometry of the Early Cambrian Mianyang-Changning intracratonic sag is with its eastern margin along the BazhongShehong-Dazhu-Hejiang zone, and its western margin along the Xinjing-Weiyuan-Qianwei zone. To the east of the sag, the thickness of the Maidiping-Canglangpu Formations is about 300-600 m, with a thickness center at the Guan'an-Hechuan area. To the west, the thickness is about $0-500 \mathrm{~m}$, with a westward decrease in thickness due to the erosion.

The Mianyang-Changning intracratonic sag can be separated into three segments, roughly separated by the WeiyuanGaoshiti area. The northern segment located at the north of the Shehong-Xinjing area has thicker Maidiping-Canglangpu Formations than the other two segments. Also its width increases northwards. In particular, some extensional faults developed in the center of the sag during the Early Cambrian times. The middle segment with a N-S striking strata is characterized by the greatest steepness of both margins of the sag. The narrowest place in the middle segment has about $50 \mathrm{~km}$ width. Furthermore, more strata of Maidiping Formation was deposited in the center, which resulted in the thickness of Maidiping-Canglangpu Formations being significantly larger than that outside the sag. The southern segment located at south of the Dazhu-Qianwei area is characterized by the least steepness of the margins and thinnest Maidiping-Canglangpu Formations than in other segments. Due to erosion, the western margin of the southern segment is not very distinct, resulting in a roughly southwestward increase in its width.

\subsection{Evolution of the Mianyang-Changning Intracratonic Sag.} Based on E-W-striking seismic sections of the MianyangCangning sag, the balanced cross-sections were constructed considering the template line as flat (e.g., the top of 


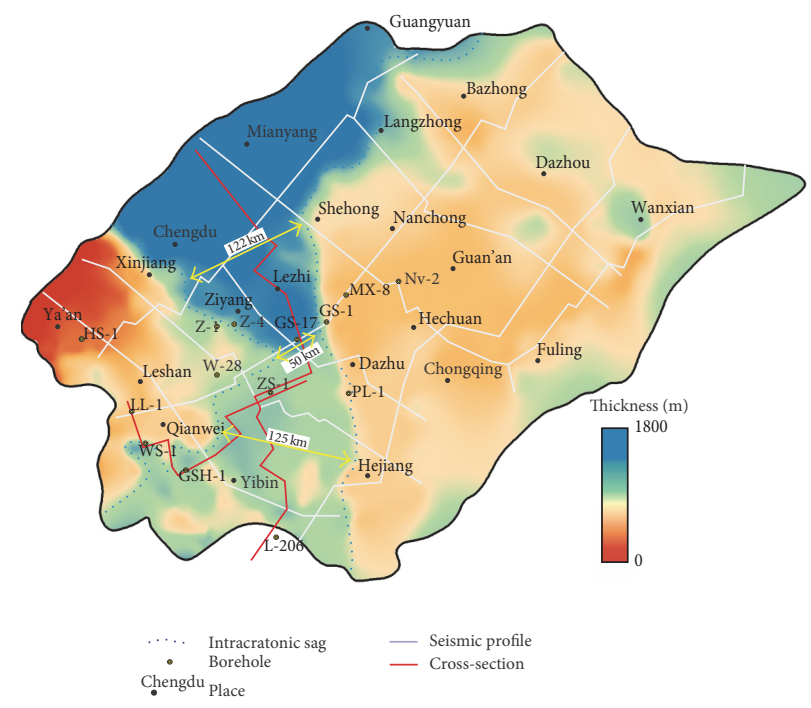

(a)

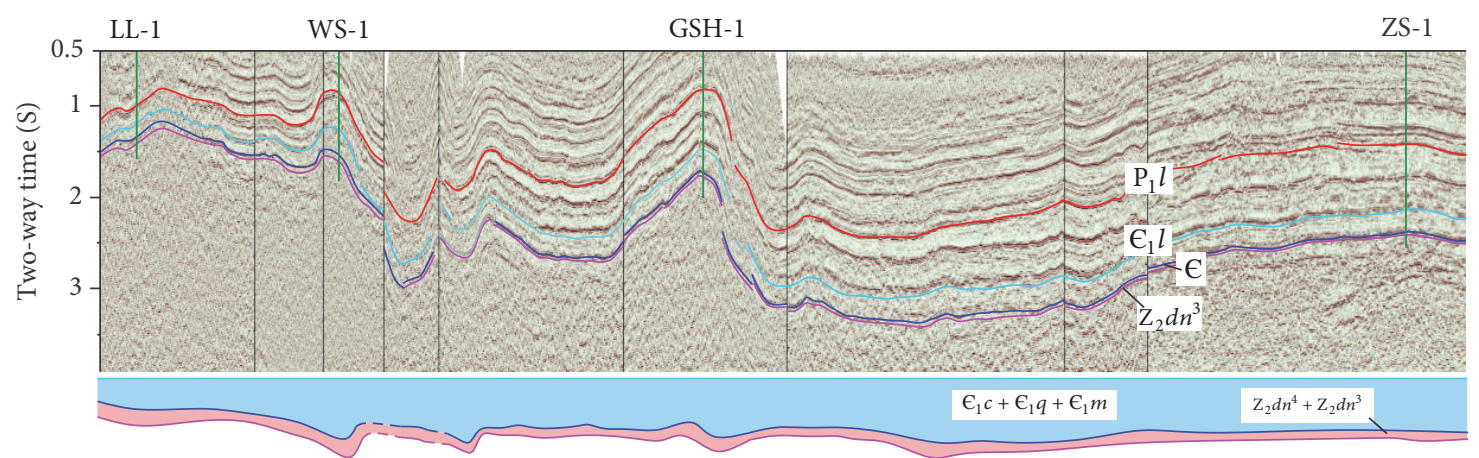

(b)

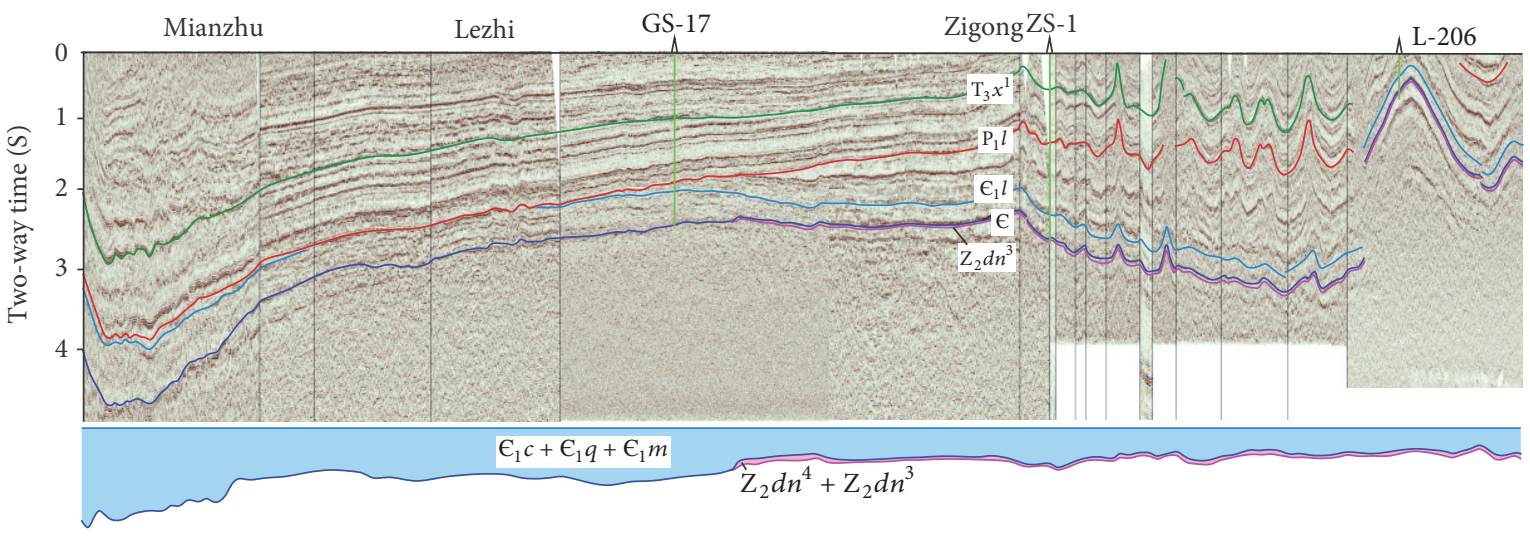

(c)

Figure 6: Cross-sections showing Early Paleozoic strata geometries in the intracratonic sag. ((a) spatial distribution of the sag indicated by the isopach map of the Maidiping-Canglangpu Formations; the sag is characterized by asymmetrical, N-S striking geometry. The sag can be subdivided into three segments; in particular, the eastern margin is much steeper than the western margin. (b) E-W striking cross-section of the sag in Leshan-Yibin-Zigong area. (c) N-S striking cross-section of the sag in Mianzhu-Changning area.)

Longwangmiao Formation, Canglangpu Formation, and Qiongzhusi Formation), to unravel the multistage history of the Mianyang-Changning intracratonic sag. Thus, the evolution of the intracratonic sag can be divided into five episodes: presag period (i.e., uplifting and erosion) at the end of Late
Sinian Dengying period, an early stage at the Early Cambrian Maidiping period, a main stage of extension during the Early Cambrian Qiongzhusi period, and a decay and dispersal stages of extension at the Early Cambrian Canglangpu and Longwangmiao periods, respectively (Figure 7). 


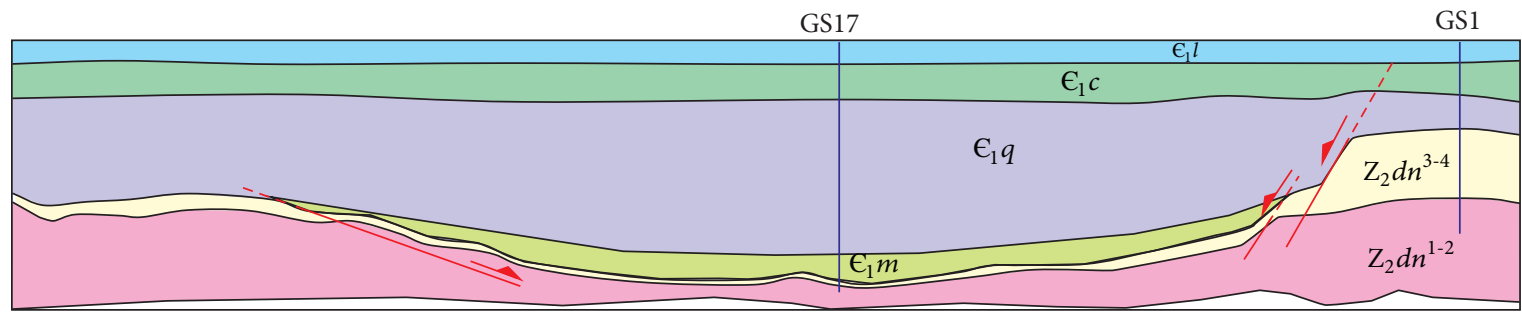

(e) Early Cambrian Longwangmiao period

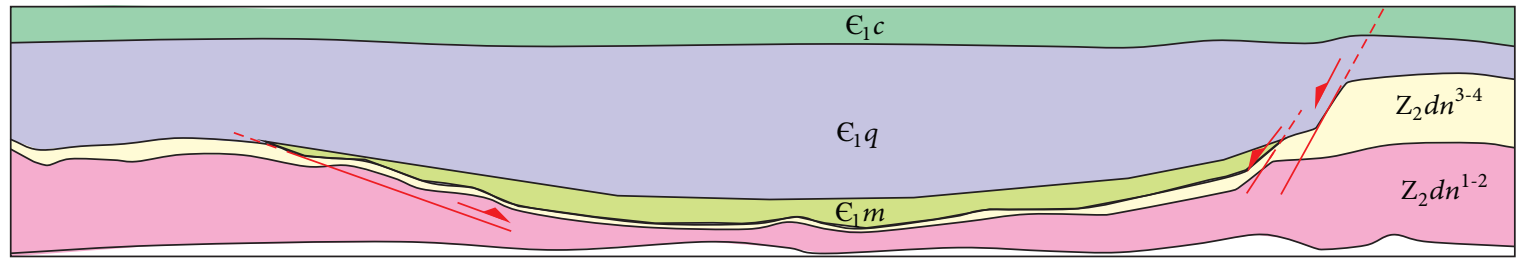

(d) Early Cambrian Canglangpu period

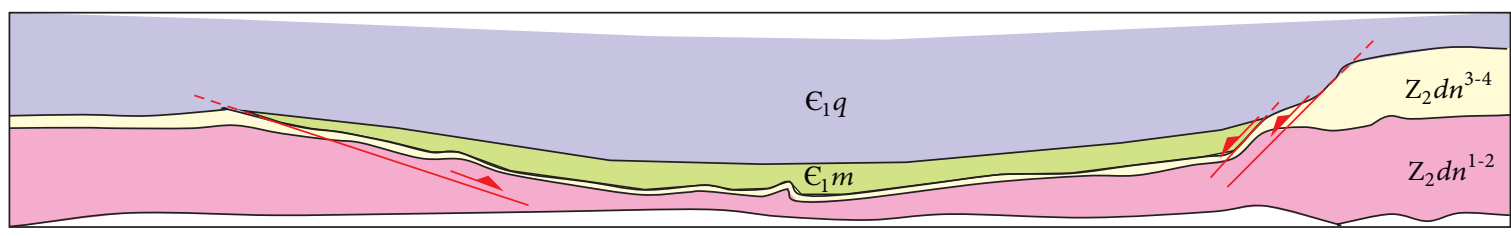

(c) Early Cambrian Qiongzhusi period

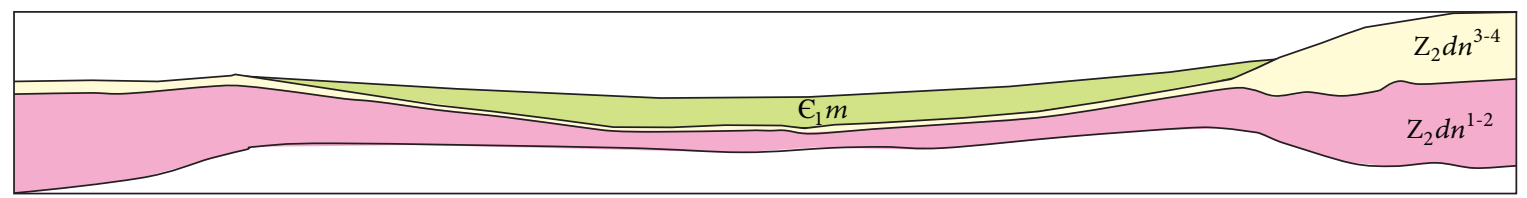

(b) Early Cambrian Maidiping period

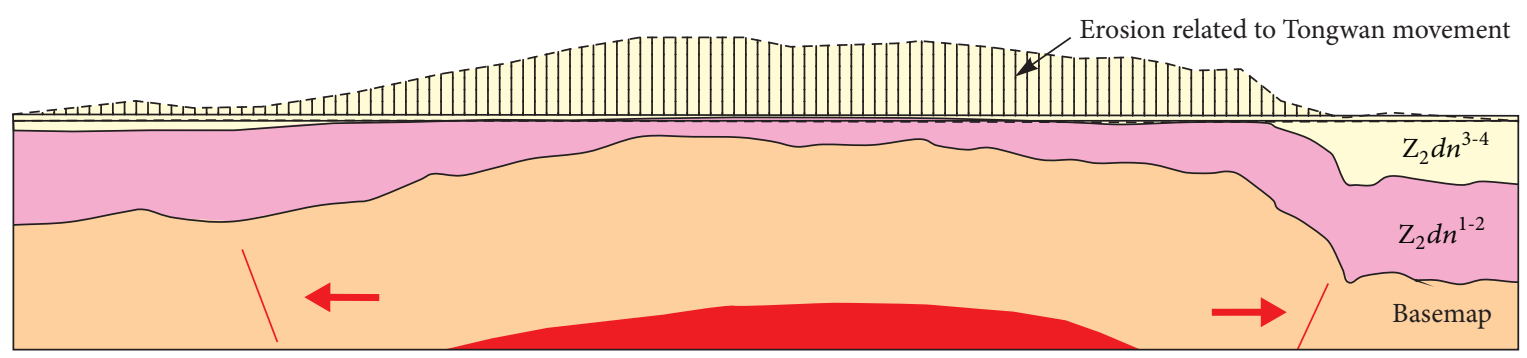

(a) End of Late Ediacaran Dengying period

Figure 7: Evolution of the Early Cambrian Mianyang-Changning intracratonic sag (it should be noted that there is more strata of Maidiping Formation and much thicker Niutitang Formation in the center of the Mianyang-Changning sag, indicating that the initial extension as well as maximum of extension occurred during the Early Cambrian Maidiping to Niutitang periods).

Widespread uplift and erosion across the Sichuan basin occurred at the end of Late Sinian Dengying period, named the "Tongwan movement" [30-32]. It is associated with different magnitudes of erosion across the sag, for example, the Z-4 and GS-17 wells located in the center of the sag lack the third and fourth members of the Dengying Formation (Table 1). This indicates that uplift and erosion across the sag were stronger than at other outside places during this time.

Early in the Early Cambrian Maidiping period, the Maidiping Formation was deposited where in presag time there was maximum erosion. This unit is characterized by deposits of black phosphorus silicic shale and phosphorus dolomite, interbedded with cellophane beds. Their occurrence is related to submarine volcanism and hydrothermal processes in a deep oceanic environment $[45,46]$, which indicates rapid subsidence and extensional tectonics. The Qiongzhusi Formation is characterized by the occurrence of black shale and mudstone at its base, and by grey-to-black muddy siltstone in the upper part of the formation, of which the geochemistry suggests it is dominated with I-type sourcerocks with high TOC content $[17,18]$. The latter indicate some shallowing, or progressive basin filing during the final stage 
of extension. The thickness of black shale in the center of the sag is up to $180 \mathrm{~m}$, for example, in the GS-17 well, which is greatly important for petroleum occurrences in the center of the Sichuan basin. The extension and sedimentation across the intracratonic sag decreased distinctly during the decay and dispersal stages at the Canglangpu and Longwangmiao periods. The Longwangmiao Formation is comprised of carbonate rocks of roughly consistent thickness across the center of Sichuan basin, indicating that the Mianyang-Changning intracratonic sag already disappeared.

\section{Control of the Intracratonic Sag on Oil/Gas Occurrences}

The development of the Mianyang-Changning intracratonic sag significantly influenced the Late Proterozoic to Early Cambrian oil/gas occurrences in the Sichuan basin, that is, chiefly through its influence on the distribution of highquality reservoirs in the Late Proterozoic Dengying and Early Cambrian Longwangmiao formations and of source-rocks in the Niutitang Formation.

4.1. High-Quality Reservoir of Late Proterozoic Dengying Formation. The reservoir characteristics of the Late Proterozoic Dengying Formation in the boreholes across the intracratonic sag indicate distinct differences in karst development, burial and hydrothermal dissolution, porosity and permeability, and so on (Table 2). There were variable magnitudes of erosion across the Mianyang-Changning intracratonic sag (Table 1, Figure 7); therefore there are variable occurrences of karst caves impacting the reservoir. The Z-1 and GS-1 wells located around the edges of the intracratonic sag have much higher density of karst caves than the JS-1 and W-113 wells, located further away from the western sag boundary. Furthermore, there are different volumes of bitumen in the reservoir of the Dengying Formation, indicating different magnitudes of burial dissolution. Westward of the intracratonic sag, no bitumen is present in the 2nd and 4 th member of the Dengying Formation at the JS-1 well. Eastward, near the sag boundary, the $\mathrm{W}-113$ well shows widespread bitumen in the 2nd and 4th members of the Dengying Formation, extending for $96.42 \mathrm{~m}$ in a $110.42 \mathrm{~m}$ long core in the $2 \mathrm{nd}$ member and for $14.82 \mathrm{~m}$ in a $23.6 \mathrm{~m}$ long core of the 4 th member, respectively. The bitumen impregnated $1 \% \sim 6 \%$ in porosity, in both the 2nd and 4 th members of the Dengying Formation, as well as in the Z-1 well, located at the western margin of the sag. In particular, a core $31.05 \mathrm{~m}$ long in the GS-1 well, located at the eastern margin of the sag, is totally impregnated by bitumen in the 4th member of the Dengying Formation, indicating much more burial dissolution along the eastern margin.

It should be noted that the porosity and permeability across the sag show significant differences. The strata in JS1 well show poor porosity and permeability. The reservoir is comprised of dissolution pores and fractures, with most of them totally or partially filled with dolomite. To the east along the intracratonic sag, the Z-1 and GS-1 wells Dengying Formation strata have much better porosity and permeability than the JS-1 and W-113 wells, in which the reservoir is represented by dissolution pores and caverns. In particular, the thickness of reservoir in the GS-1 well is up to $184.05 \mathrm{~m}$, with a gas production of $10^{6} \mathrm{~m}^{3}$ per day. It indicates that a better porosity and permeability in the reservoir is located along the border of the intracratonic sag. That is consistent with a distinct increase in the karst weathering, dissolution pores occurrence, presence of bitumen in the reservoir, and intensity of burial and hydrothermal dissolution towards the sag.

4.2. High-Quality Source-Rock of Early Cambrian Niutitang Formation. During development of the Early Cambrian Mianyang-Cangning intracratonic sag, the 50-450 m thick Qiongzhushi/Niutitang Formation comprised of black shale was deposited (Figure 8). It should be noted that the geometry and thickness of Qiongzhushi Formation show much difference than those of the Early Cambrian MaidipingCanglangpu Formations (shown in Figure 6), which could be attributed to the interpolation of different thickness between them (i.e., the 50-450 m thick Qiongzhushi Formation and the 450-1700 $\mathrm{m}$ thick Maidiping-Canglangpu Formations). However, the thickness isopach of the Qiongzhushi Formation roughly parallels the orientation of the sag, indicating that the maximum thickness of the Qiongzhushi Formation is controlled by the morphology of the sag. Strata located around the intracratonic sag provided most of the hydrocarbons to charge its Late Proterozoic to Lower Cambrian petroleum systems $[7,18,38,39]$.

\subsection{High-Quality Reservoir of Early Cambrian Longwangmiao} Formation. Based on thin-section analyses from three wells across the intracratonic sag, different diagenesis regimes were noted in the Early Cambrian Longwanmiao Formation. A 20-60 m thick high-quality reservoir in the Anyue supergiant gas field shows dolomitization, cementation, compaction, and pressure solution. Dolomitization, selective freshwater dissolution, and liquid hydrocarbon filling had significant roles in the reservoir development, in particular the last two processes. The Longwangmiao Formation reservoir in the MX-12 well located at the eastern margin of the sag shows strong selective freshwater karstification and hydrocarbon charging, indicated by multiple episodes of bitumen filling. Also it has indications of moderate epigenic karstification and hydrothermal activity (Table 3). However, the reservoir in the boreholes located in the center of the sag shows strong epigenic karstification and hydrothermal dolomite, for example, the GS-17 well. To the west of the sag, magnitude of hydrocarbon charging, epigenic karstification, and hydrothermal dolomite decrease in the Longwangmiao Formation. For example, the JS-1 well demonstrates only weak epigenic karstification and no hydrocarbon charging. Thus, it suggests that the high-quality reservoir in the Longwangmiao Formation is associated with the intracratonic sag development. Most importantly, the best reservoirs of Longwangmiao Formation are located at the eastern margin of the sag.

There are two reasons which may explain the occurrence of a high-quality reservoir at the eastern margin of the sag in the Early Cambrian Longwanmiao Formation. During extensional tectonics, the footwall of the intracratonic sag may have formed a paleohigh along its margins. Although the difference in elevation between the paleohigh of the 

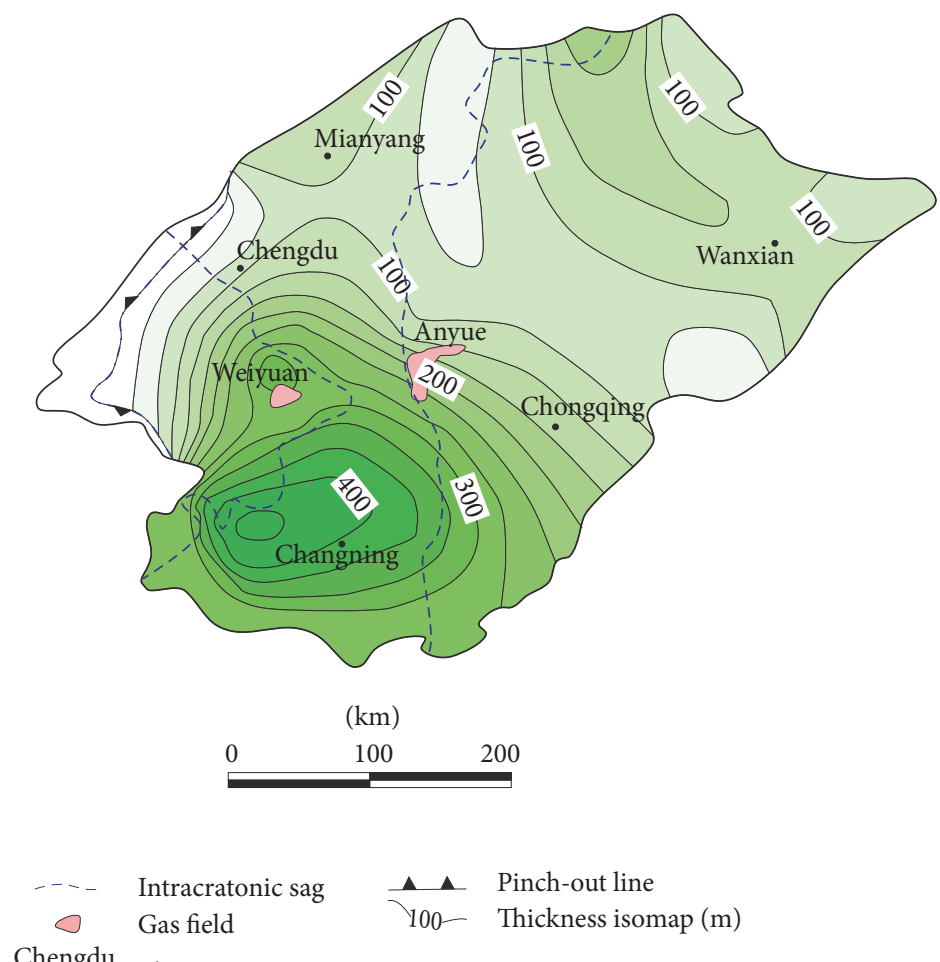

(a)
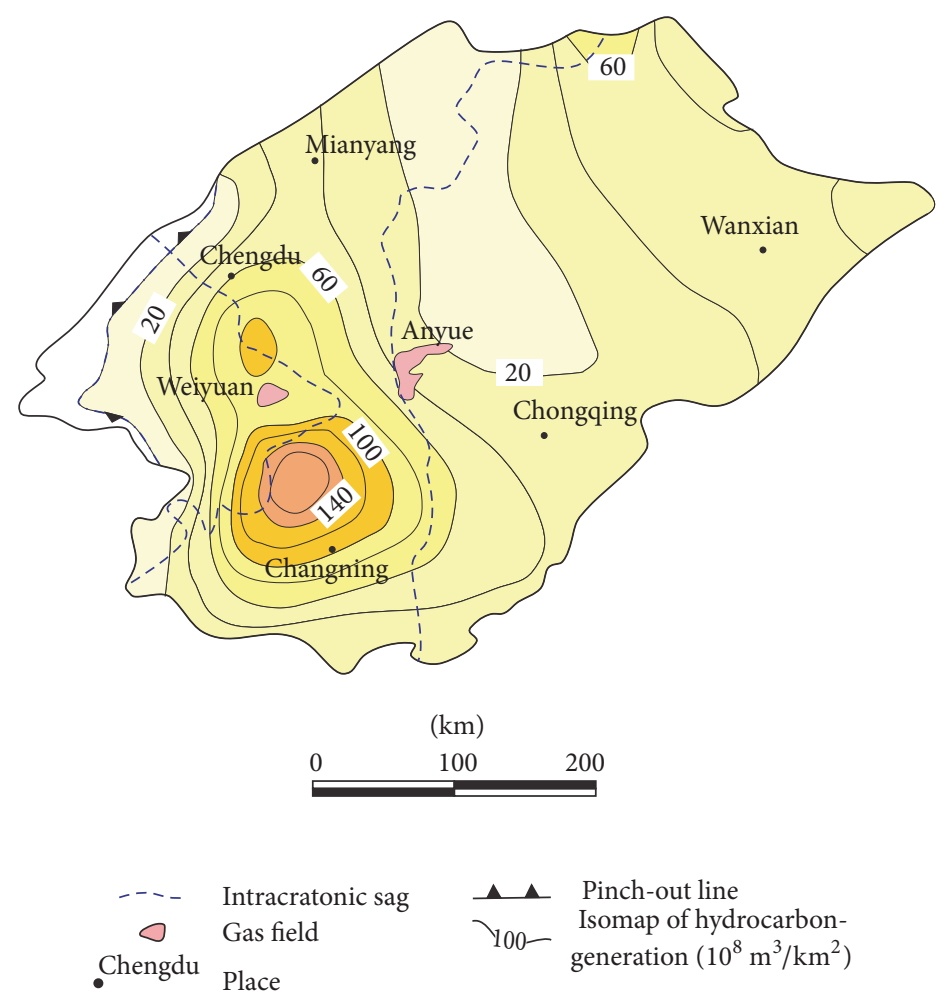

(b)

FIGURE 8: The thickness and hydrocarbon-generating intensity of the Lower Cambrian mudstone across the Sichuan basin ((a) Thickness isopach map of the Qiongzhushi/Niutitang Formation; (b) isomap of hydrocarbon-generation of the Qiongzhushi/Niutitang Formation, modified from Huang et al., 2002 [18]). 
TABLE 2: Reservoir features of the Ediacaran Dengying Formations across the intracratonic sag.

\begin{tabular}{lcccc}
\hline Wells & JS-1\# & W-113\# & Z-1\# & GS-1\# \\
\hline Locations & & Western margin of the sag & Eastern margin \\
Reservoir & 2nd member & 3rd and 4 th members & 2nd and 3rd members & 2nd and 4th members \\
Porosity & $3.02 \%-4.05 \%$ & $1 \%-5 \%$ & $1 \%-2 \%$ & $2.45 \%-4.85 \%$ \\
Permeability & $0.0063-5.9317 \mathrm{mD}$ & $0.1-1.92 \mathrm{~m}$ & $0.00225-88.2 \mathrm{mD}$ & $1.005-8.02 \mathrm{mD}$ \\
Bitumen content & No & $1 \% \sim 6 \%$ & $1 \% \sim 5 \%$ & $1 \% \sim 5 \%$ \\
Pore type & Dissolved pore & Fracture and pore & Dissolved pore & Dissolved pore \\
Fracture density & $15.3 / \mathrm{m}$ & $24.75 / \mathrm{m}$ & $4.22 / \mathrm{m}$ & $1.4 / \mathrm{m}$ \\
Density of karst cave & $0.75 / \mathrm{m}$ & $1.3 / \mathrm{m}$ & $25 / \mathrm{m}$ & $11.4 / \mathrm{m}$ \\
Vugs-filling minerals & Dolomite & Dolomite-saddle dolomite-bitumen & Saddle dolomite-bitumen & Saddle dolomite-bitumen \\
Weathering karst & Weak & Medium & Strong & Very strong \\
Burial dissolution & Weak & Moderate strong & Strong & Very strong \\
Hydrothermal dissolution & Weak & Moderate strong & Strong & Very strong \\
\hline
\end{tabular}

(For locations, see Figure 1.)

TABLE 3: Differential diagenesis of Early Cambrian Longwangmiao Formation across the intracratonic sag.

\begin{tabular}{lccc}
\hline Well & JS-1 & GS-17 & MX-12 \\
\hline Location & Western margin of sag & Center of sag & Eastern margin \\
Lithology & Crystalline dolomite & Dolomitic grainstone, crystalline dolomite & Dolomitic grainstone \\
Mudstone recrystallization & No & Weak & Weak \\
Dolomitization & Strong & Strong & Strong \\
Cementation & Weak & Moderate & Strong \\
Freshwater karstification & Weak & Moderate & Strong \\
Compaction, pressure solution & Moderate & Moderate & Moderate \\
Recrystallization & Strong & Strong & Strong \\
Epigenic karstification & Weak & Moderate to strong & Moderate \\
Hydrothermal dolomite & Moderate & Strong & Moderate \\
First charging of hydrocarbon and bitumen & No & Moderate & Strong \\
Second charging of hydrocarbons & No & Moderate & Strong \\
\hline
\end{tabular}

(For locations, see Figure 1.)

footwall and hanging wall may not be substantial, it had significant influence on reservoir development. Our studies of seismic data support existence of such a paleohigh during deposition of the Longwanmiao Formation. The MoxiGaoshiti area (in Figure 1 the MX-GS area) had maximum paleoelevation during that time period. Thus, we suggest that the paleohigh formed at the sag margin was conducive for a grainstone-bank facies deposition during Longwangmiao Formation time. The thickness of this facies is $20-70 \mathrm{~m}$ at the Moxi-Gaoshiti area. Subsequent surface exposure resulted in freshwater karstification and development of intergranular and intragranular dissolution porosity.

The lower part of the Lower Cambrian had significant capacity to generate oil/gas, which together with hydrocarbons from the Ediacaran Sinian strata migrated to Early Paleozoic traps $[7,37,38]$. The critical time periods for hydrocarbons generation, migration, and transformation were the Silurian, which was the initial period for liquid hydrocarbons generation, Late Permian to Late Triassic period for peak hydrocarbon-generation, and the Middle Jurassic to Late Cretaceous interval for hydrocarbon-cracking into gas [7, 47]. Furthermore, the paleouplift of Leshan-Longnvshi formed during Late Carboniferous-Early Permian period and is roughly prior to the period of peak hydrocarbon-generation $[48,49]$; we argue that the paleohigh along the margins of the intracratonic sag has the highest probability to be charged by hydrocarbons, as maturity of the source-rocks was increasing with increased burial.

Study of thin-sections indicates that there are two periods of hydrocarbon charging: the first one during shallow-moderate burial of the strata and the second one during moderateto-deep burial. The first one followed a period of uplift and freshwater karstification of exposed carbonate strata, which occurred at the Sinian-Cambrian boundary, and is marked by the unconformity. Occurrence of trace amounts of bitumen suggests that limited hydrocarbon-generation may have occurred due to the presence of hot hydrothermal fluids, indicated by $\mathrm{Pb}-\mathrm{Zn}$ mineralization near the boundary. The 


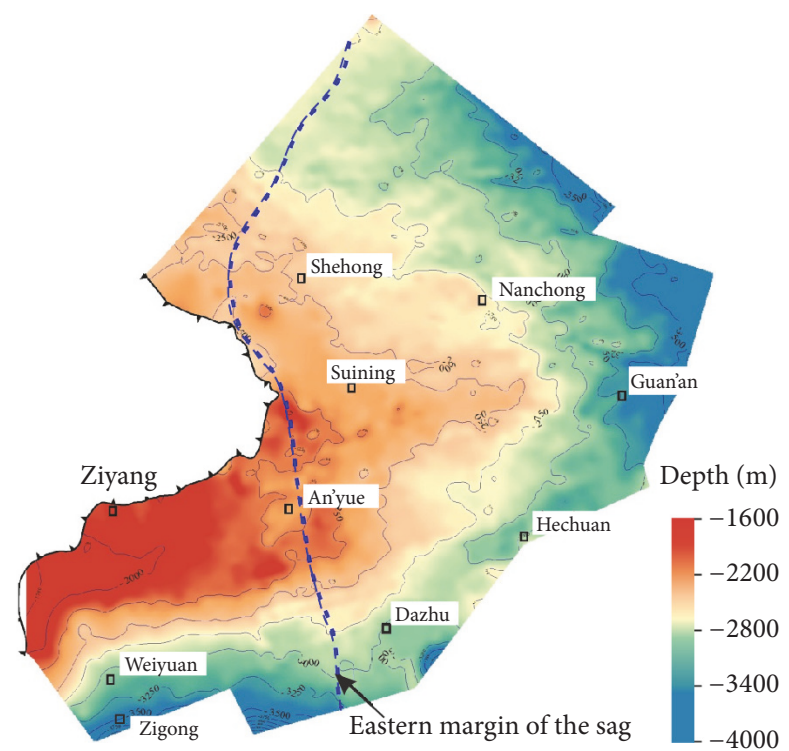

(a)

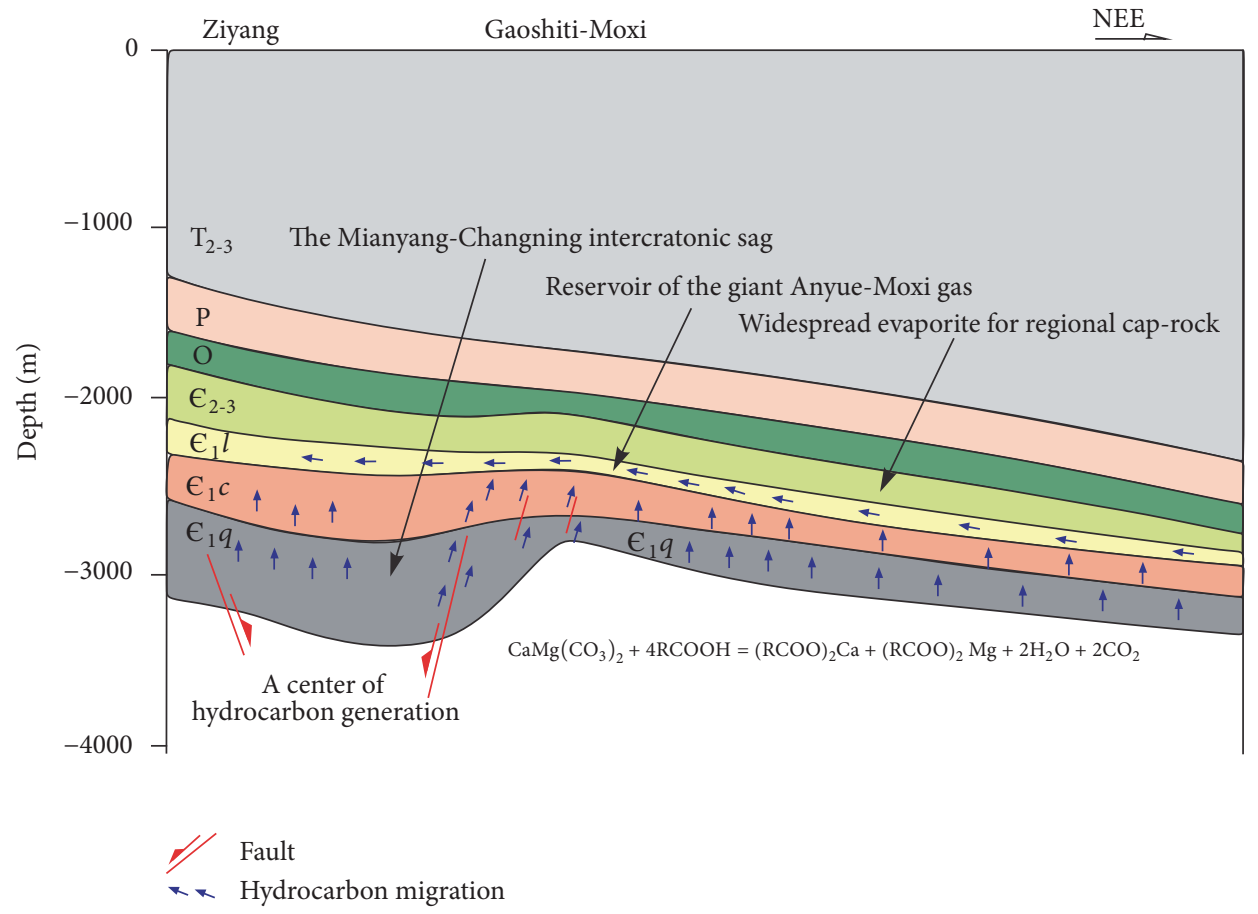

(b)

Figure 9: Conceptual model of high-quality reservoir rocks of Early Cambrian Longwangmiao Fm in the central Sichuan basin. ((a) Paleostructure of Longwangmiao Fm at the end of Permian, (b) hydrocarbon charging model of Qiongzhushi Fm).

increased burial resulted in increased thermal maturity of the source-rocks and the main peak of hydrocarbon-generation during the Permian. The Gaoshiti-Moxi and Weiyuan-Ziyang areas located at the eastern and western margins of the sag represent the best area for hydrocarbon charging and migration (Figure 9). Both of those areas contain highquality reservoirs in the Longwangmiao Formation. Also there is a steeper margin at the eastern margin of the sag than its west, which would contribute to a better efficiency of hydrocarbon migration. Furthermore, the Gaoshiti-Moxi and Weiyuan-Ziyang areas were located at the paleohigh and upper slope during the deposition of Longwangmiao Formation. Both of them account for most of high-quality reservoirs in the Gaoshiti-Moxi area. Therefore, we suggest that the most prospective areas characterized by occurrence of high-quality reservoirs and hydrocarbons accumulation in 
Longwangmiao Formation are at the eastern part of the overlapping areas of the Mianyang-Changning intracratonic sag and the paleouplift, represented by the Gaoshiti-Moxi area.

\section{Conclusions}

The Neoproterozoic break-up of the Rodinia supercontinent, that is, Xinkai taphrogenesis in the South China block, had significant influence on the Neoproterozoic-Early Cambrian hydrocarbon occurrences in the Sichuan basin. Our study shows an asymmetrical, S-N striking intracratonic sag, that is, the Mianyang-Changning intracratonic sag, which developed across the Sichuan basin from the Late Ediacaran to Early Cambrian time. The sag can be divided into three segments, with margins roughly along the Bazhong-Shehong-DazhuHejiang area at the eastern margin and the Xinjing-WeiyuanQianwei area at the western margin. In particular, the eastern margin shows much greater steepness than the western margin. The narrowest part of the sag is $\sim 50 \mathrm{~km}$ across, and its greatest steepness is in the basin center. Five episodes of evolutions of the sag can be established. It begins in the Late Ediacaran with an uplift and erosion correlated to Tongwan movement preceding extension. Initial extension occurred in the Early Cambrian Maidiping period, with strata of the Maidiping Formation deposited across the Mianyang-Changning sag. Subsequently, maximum of extension took place at the Early Cambrian Qiongzhusi period that resulted in deposition of the 450-1700 m thick MaidipingCanglangpu Formations in the center of the sag. Finally, the sag was infilled by sediments at the end of the Early Cambrian (i.e., the Longwangmiao period) and as structural entity disappeared.

The Mianyang-Changning intracratonic sag had significant influence on the Late Proterozoic to Early Cambrian hydrocarbon occurrences in the Sichuan basin. It is chiefly through its influence on the presence of high-quality reservoirs rocks in the Late Proterozoic Dengying and Early Cambrian Longwangmiao formations and distribution of sourcerocks of the Niutitang Formation. During the evolution of the Mianyang-Changning sag, the paleohighs and erosion account for the development of high-quality reservoirs in the Late Proterozoic Dengying and Early Cambrian Longwangmiao formations. Furthermore, it was the sag development which provided conditions favorable for the deposition of Itype source-rock of the Niutitang Formation. Considering all of these factors there is a high probability of oil/gas accumulation along the Mianyang-Cangning intracratonic sag, particularly along its eastern margin across the center of the Sichuan basin.

\section{Conflicts of Interest}

The authors declare that they have no conflicts of interest.

\section{Acknowledgments}

This work was supported by the National Basic Research Program of China (no. 2012CB214805) and the Natural Science Foundation (nos. 41230313, 41402119, and 41472017).
The authors are thankful to Frank Thomas for review of the English in the manuscript.

\section{References}

[1] S. I. Fraser, A. J. Fraser, M. R. Lentini, and R. L. Gawthorpe, "Return to rifts - The next wave: Fresh insights into the petroleum geology of global rift basins," Petroleum Geoscience, vol. 13, no. 2, pp. 99-104, 2007.

[2] J. Craig, J. Thurow, B. Thusu, A. Whitham, and Y. Abutarruma, "Global Neoproterozoic petroleum systems: The emerging potential in North Africa," Geological Society Special Publication, vol. 326, pp. 1-25, 2009.

[3] F. Lottaroli, J. Craig, and B. Thusu, "Neoproterozoic-Early Cambrian (Infracambrian) hydrocarbon prospectivity of North Africa: A synthesis," Geological Society Special Publication, vol. 326, pp. 137-156, 2009.

[4] A. A. Meyerhoff, "Geology and petroleum fields in Proterozoic and lower Cambrian strata, Lena-Tunguska petroleum province, Eastern Siberia, USSR," in Giant Oil and Gas Fields of the Decade 1968-1978, M. T. Halbouty, Ed., vol. 30, pp. 225-252, AAPG Memoir, 1980.

[5] K. A. R. Ghori, J. Craig, B. Thusu, S. Lüning, and M. Geiger, "Global Infracambrian petroleum systems: A review," Geological Society Special Publication, vol. 326, pp. 109-136, 2009.

[6] G. M. Bhat, J. Craig, M. Hafiz et al., "Geology and hydrocarbon potential of neoproterozoic-cambrian basins in asia: An introduction," Geological Society Special Publication, vol. 366, no. 1, pp. 1-17, 2012.

[7] S. G. Liu, C. Qin, L. Jansa et al., “Transformation of oil pools into gas pools as results of multiple tectonic events in Upper Sinian (Upper Neoproterozoic), deep part of Sichuan Basin, China," Energy Exploration and Exploitation, vol. 29, no. 6, pp. 679-698, 2011.

[8] J. M. Peters, J. B. Filbrandt, J. P. Grotzinger, M. J. Newall, M. Shuster, and H. A. Al-Siyabi, "Surface-piercing salt domes of interior North Oman, and their significance for the Ara carbonate 'stringer' hydrocarbon play," GeoArabia, vol. 8, no. 2, pp. 231-270, 2003.

[9] J. Schoenherr, R. Littke, J. L. Urai, P. A. Kukla, and Z. Rawahi, "Polyphase thermal evolution in the Infra-Cambrian Ara Group (South Oman Salt Basin) as deduced by maturity of solid reservoir bitumen," Organic Geochemistry, vol. 38, no. 8, pp. 1293-1318, 2007.

[10] A. Wyatt, Challinors Dictionary of Geology, University of Wales Press, Cardiff, Wales, 6th edition, 1986.

[11] A. G. Smith, "A review of the ediacaran to early cambrian ('Infra-Cambrian') evaporites and associated sediments of the middle east," Geological Society Special Publication, vol. 366, no. 1, pp. 229-250, 2012.

[12] C. Zhong and J. Huang, Drilling and Gas Recovery Technology in Ancient, Zigong Salt Industry Museum, Sichuan, China, 1997.

[13] R. J. Korsch, M. Huazhao, S. Zhaocai, and J. D. Gorter, "The Sichuan basin, southwest China: a late proterozoic (Sinian) petroleum province," Precambrian Research, vol. 54, no. 1, pp. 45-63, 1991.

[14] Y. C. Xu and P. Shen, "A study of natural gas origins in China," AAPG Bulletin, vol. 80, no. 10, pp. 1604-1614, 1996.

[15] J. Zhang and Q. Zhang, "The review and prospects of oil and gas exploration in Sichuan basin," Natural Gas Industry, vol. 22, pp. 3-7, 2002. 
[16] Y. Ma, X. Guo, T. Guo, R. Huang, X. Cai, and G. Li, "The Puguang gas field: New giant discovery in the mature Sichuan Basin, southwest China," AAPG Bulletin, vol. 91, no. 5, pp. 627643, 2007.

[17] C. N. Zou, J. H. Du, C. C. Xu et al., "Formation, distribution, resource potential and discovery of the Sinian-Cambrian giant gas field, Sichuan Basin, SW China," Petroleum Exploration and Development, vol. 41, no. 3, pp. 278-293, 2014.

[18] X. P. Huang, S. Q. Wang, and Q. H. Luo, Oil and Gas Resource Evaluation in Sichuan Basin, PetroChina Southwest Oil \& Gas Field Company, Chengdu, China, 2002.

[19] Y. Dong, G. Zhang, F. Neubauer, X. Liu, J. Genser, and C. Hauzenberger, "Tectonic evolution of the Qinling orogen, China: review and synthesis," Journal of Asian Earth Sciences, vol. 41, no. 3, pp. 213-237, 2011.

[20] F. Roger, M. Jolivet, and J. Malavieille, "The tectonic evolution of the Songpan-Garzê (North Tibet) and adjacent areas from Proterozoic to Present: A synthesis," Journal of Asian Earth Sciences, vol. 39, no. 4, pp. 254-269, 2010.

[21] S. Liu, B. Deng, Z. Li et al., "Geological evolution of the longmenshan intracontinental composite orogen and the eastern margin of the Tibetan Plateau," Journal of Earth Science, vol. 24, no. 6, pp. 874-890, 2013.

[22] S. Li, M. Santosh, G. Zhao, G. Zhang, and C. Jin, "Intracontinental deformation in a frontier of super-convergence: A perspective on the tectonic milieu of the South China Block," Journal of Asian Earth Sciences, vol. 49, pp. 313-329, 2012.

[23] Z.-X. Li and X.-H. Li, "Formation of the 1300-km-wide intracontinental orogen and postorogenic magmatic province in Mesozoic South China: A flat-slab subduction model," Geology, vol. 35, no. 2, pp. 179-182, 2007.

[24] X.-H. Li, "U-Pb zircon ages of granites from the southern margin of the Yangtze Block: Timing of Neoproterozoic Jinning: Orogeny in SE China and implications for Rodinia assembly," Precambrian Research, vol. 97, no. 1-2, pp. 43-57, 1999.

[25] M.-F. Zhou, D.-P. Yan, P. M. Vasconcelos, J.-W. Li, and R.-Z. Hu, "Structural and geochronological constraints on the tectonothermal evolution of the Danba domal terrane, eastern margin of the Tibetan plateau," Journal of Asian Earth Sciences, vol. 33, no. 5-6, pp. 414-427, 2008.

[26] J.-H. Yu, S. Y. O’Reilly, L. Wang et al., "Where was South China in the Rodinia supercontinent?. Evidence from $\mathrm{U}-\mathrm{Pb}$ geochronology and Hf isotopes of detrital zircons," Precambrian Research, vol. 164, no. 1-2, pp. 1-15, 2008.

[27] F. H. Hou, S. X. Fang, X. Z. Wang et al., "Review of Sinian Dengying formation reservoir and permeability in Sichuan basin," Acta Petrolei Sinica, vol. 20, pp. 16-21, 1999.

[28] W. Li, J. Liu, S. Deng, B. Zhang, and H. Zhou, "The nature and role of Late Sinian-Early Cambrian tectonic movement in Sichuan Basin and its adjacent areas," Shiyou Xuebao/Acta Petrolei Sinica, vol. 36, no. 5, pp. 546-563, 2015.

[29] S. G. Liu, W. Sun, Y. H. Zhao et al., "Differential accumulation and distribution of natural gas and their main controlling factors in the Upper Sinian Dengying Fm, Sichuan Basin," Natural Gas Industry, vol. 35, no. 1, pp. 10-23, 2015.

[30] J. Q. Huang, J. S. Ren, and C. F. Jiang, Tectonic and Geotectonic Evolution of China: A Brief Introduction of the Tectonic Map of China (1: 4000 000), Science Press, Beijing, China, 1980.

[31] Z. L. Luo, "The influence on the formation oil and mineral resources from taphrogenesis movement since the late Paleozoic in southwest China," Acta Geologica Sichuan, vol. 2, pp. 1$22,1981$.
[32] Z. L. Luo, "A discussion of taphrogenesis and hydrocarbon distribution in China," Acta Geologica Sichuan, vol. 3, pp. 93101,1984

[33] Z. X. Li, S. V. Bogdanova, A. S. Collins et al., "Assembly, configuration, and break-up history of Rodinia: a synthesis," Precambrian Research, vol. 160, no. 1-2, pp. 179-210, 2008.

[34] Z. Chen M and Q. Chen Y, "The Paleogeography in early Meizhucun period of Early Cambrian at Yangtze platform and distribution of phosphorite," Scientia Geologica Sinica, vol. 3, pp. 246-256, 1987.

[35] G. Z. Wang, S. G. Liu, C. H. Chen, D. Wang, and W. Sun, "The genetic relationship between MVT $\mathrm{Pb}-\mathrm{Zn}$ deposits and paleooil/gas reservoirs at Heba, Southeastern Sichuan Basin," Earth Science Frontiers, vol. 20, no. 1, pp. 107-116, 2013.

[36] S. G. Liu, W. M. Huang, L. F. Jansa et al., "Hydrothermal Dolomite in the Upper Sinian (Upper Proterozoic) Dengying Formation, East Sichuan Basin, China," Acta Geologica Sinica-English Edition, vol. 88, no. 5, pp. 1466-1487, 2014.

[37] S. G. Liu, Y. S. Ma, W. Sun et al., "Studying on the differences of Sinian natural gas pools between Weiyuan gas field and Ziyang gas-brone area, Sichuan basin," Acta Geologica Sinica, vol. 82, no. 3, pp. 328-337, 2008.

[38] G. Wei, G. Chen, S. Du, L. Zhang, and W. Yang, "Petroleum systems of the oldest gas field in China: Neoproterozoic gas pools in the Weiyuan gas field, Sichuan Basin," Marine and Petroleum Geology, vol. 25, no. 4-5, pp. 371-386, 2008.

[39] G. Zhu, T. Wang, Z. Xie, B. Xie, and K. Liu, “Giant gas discovery in the Precambrian deeply buried reservoirs in the Sichuan Basin, China: Implications for gas exploration in old cratonic basins," Precambrian Research, vol. 262, pp. 45-66, 2015.

[40] B. C. Burchfiel and L. H. Royden, "Tectonics of the Longmen Shan and adjacent regions, central China," International Geology Review, vol. 37, no. 8, pp. 661-735, 1995.

[41] Z. Jin, Y. Yuan, Q. Liu, and Y. Wo, "Controls of Late JurassicEarly Cretaceous tectonic event on source rocks and seals in marine sequences, South China," Science China Earth Sciences, vol. 56, no. 2, pp. 228-239, 2013.

[42] J. Wang, "Relationship between tectonic evolution and hydrocarbon in the foreland of the Longmen mountains," Journal of Southeast Asian Earth Sciences, vol. 13, no. 3-5, pp. 327-336, 1996.

[43] S. Liu, B. Deng, Z. Li, and W. Sun, "Architecture of basinmountain systems and their influences on gas distribution: A case study from the Sichuan basin, South China," Journal of Asian Earth Sciences, vol. 47, pp. 204-215, 2012.

[44] P. A. Allen and J. R. Allen, Basin Analysis: Principles and Application to Petroleum Play Assessment, Wiley-Blackwell, Chichester, UK, 2013.

[45] W.-H. Zhang, L.-J. Jiang, H. Gao, and R.-D. Yang, "Study on sedimentary environment and origin of black siliceous rocks of the Lower Cambrian in Giuzhou Province," Bulletin of Mineralogy Petrology and Geochemistry, vol. 22, no. 2, pp. 174-178, 2003.

[46] J. Wang, D. Chen, D. Wang, D. Yan, X. Zhou, and Q. Wang, "Petrology and geochemistry of chert on the marginal zone of Yangtze Platform, western Hunan, South China, during the Ediacaran-Cambrian transition," Sedimentology, vol. 59, no. 3, pp. 809-829, 2012.

[47] J. Z. Huang, S. J. Cheng, L. S. Song Wang Jr., X. M. Gou, T. D. Wang, and H. M. Dai, "Hydrocarbon system of the Sichuan basin and formation of the medium-to-large gas fields," Science in China (Series D), vol. 26, pp. 504-510, 1996. 
[48] Y. C. Kang, "The formation and development of Paleo-uplift in central Sichuan and its oil/gas prospect," Experimental Petroleum Geology, vol. 10, pp. 12-23, 1988.

[49] Y. Zhong, Y.-L. Li, X.-B. Zhang et al., "Evolution characteristics of Central Sichuan palaeouplift and its relationship with early Cambrian Mianyang-Changning intracratonic sag," Journal of Chengdu University of Technology (Science and Technology Edition), vol. 41, no. 6, pp. 703-712, 2014. 

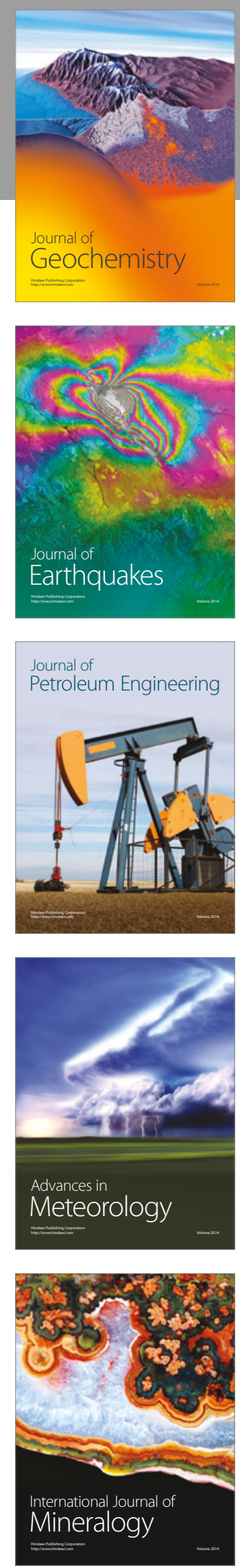
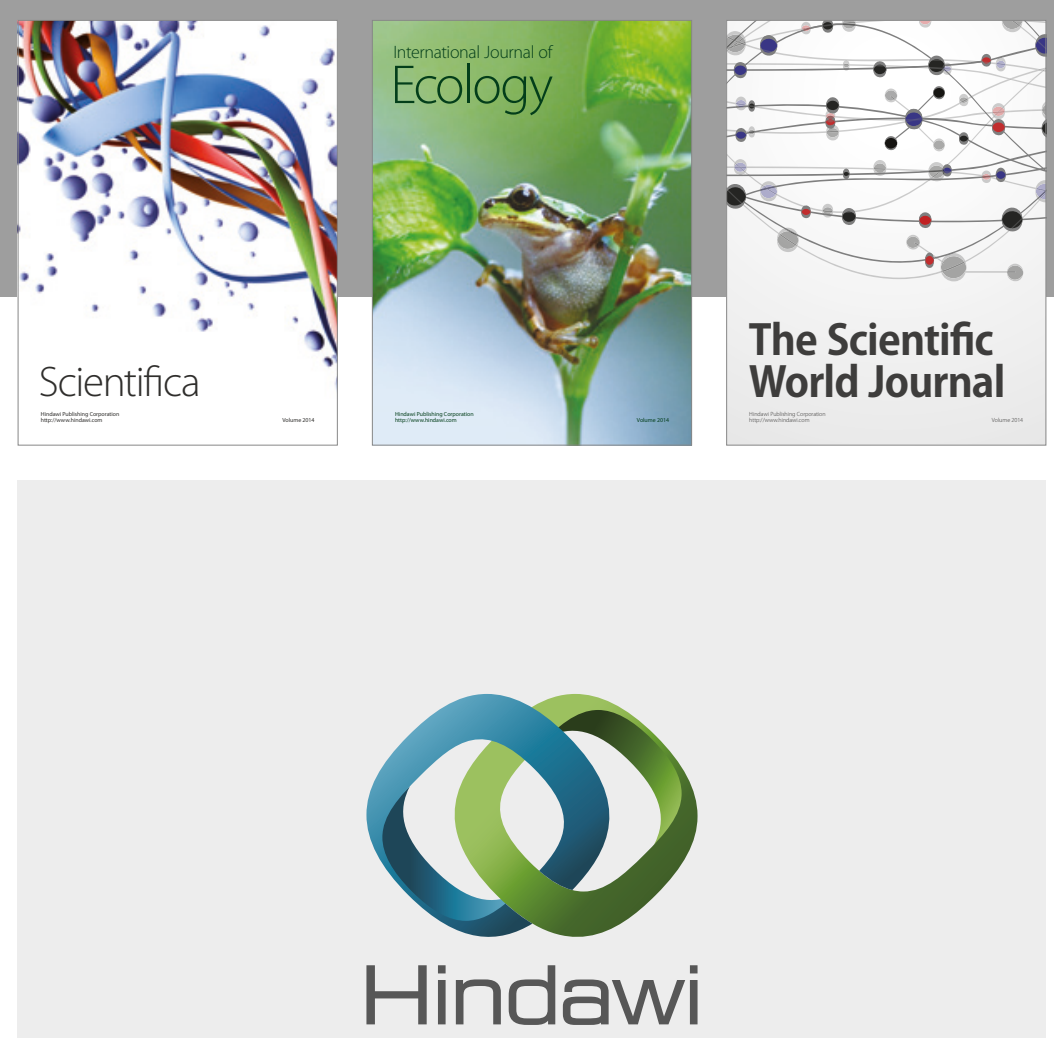

Submit your manuscripts at

https://www.hindawi.com
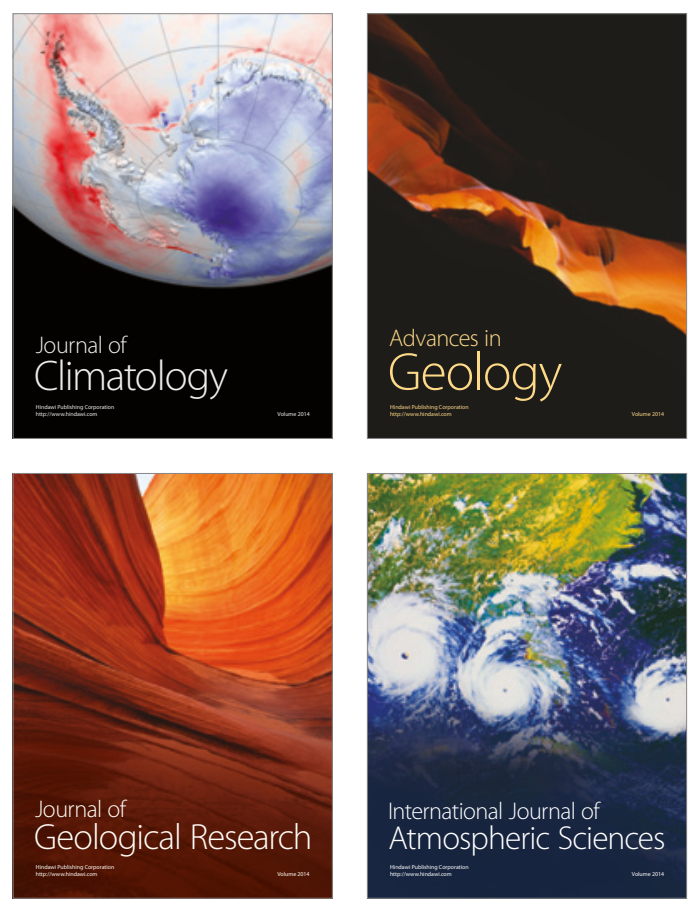

The Scientific

World Journal
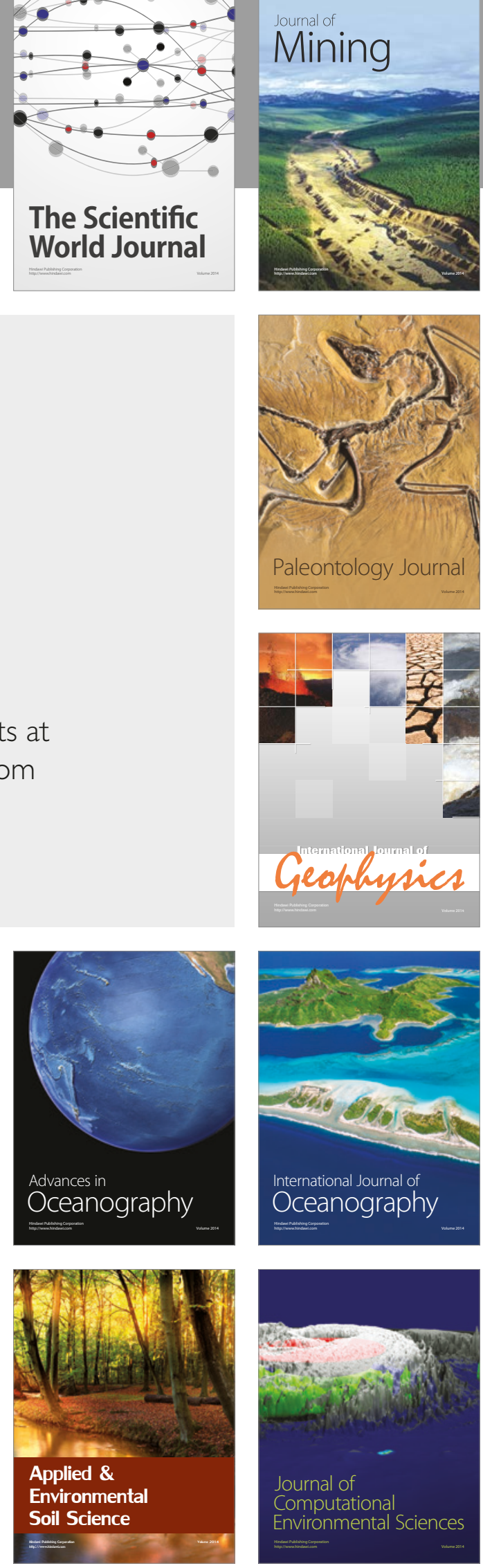